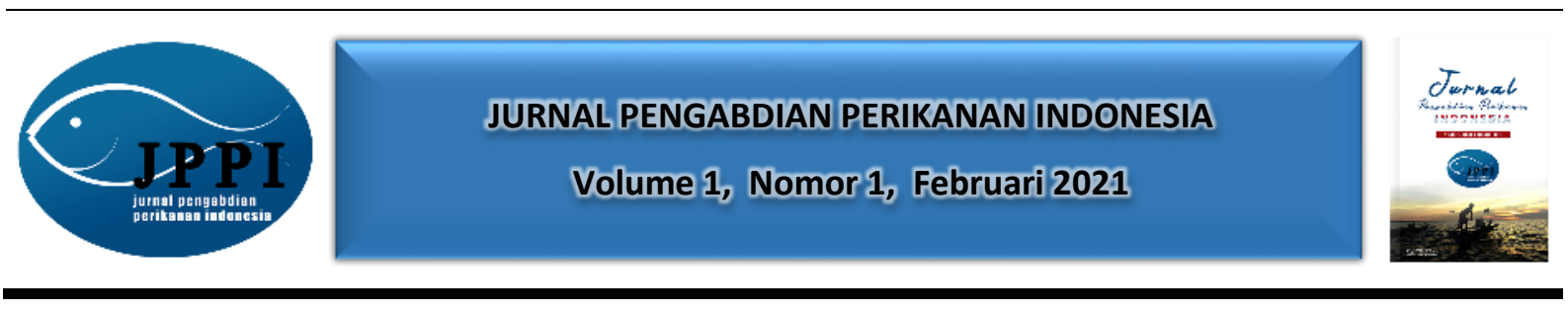

\title{
PENYUSUNAN RENCANA PENGELOLAAN SUMBERDAYA PESISIR BERBASIS MASYARAKAT DI DESA BATU NAMPAR SELATAN KEBUPATEN LOMBOK TIMUR
}

\author{
Syarif Husni, Lalu Sukardi, Muhammad Yusuf, Muhammad Nursan, Aeko Fria Utama FR
}

\author{
Program Studi Agribisnis Fakultas Pertanian Universitas Mataram
}

Jalan Majapahit Nomor 62 Kota Mataram

Alamat korespondensi : syarifhusni1964@gmail.com

(Tanggal Submission: 3 Desember 2020, Tanggal Accepted : 2 Februari 2021)

\begin{abstract}
Keyword : Abstrak :
pengelolaan Tujuan pengabdian: a) Mengidentifikasi isu dan permasalahan yang dihadapi masyarakat sumberdaya dalam pemanfaatan sumberdaya pesisir dan b) menyusun Rencana Pengelolaan sumberdaya pesisir, berbasis masyarakat pesisir pesisir di Desa Batu Nampar Selatan. Metode pelaksanaan penyusunan Rencana Pengelolaan sumberdaya Pesisir berbasis masyarakat ini terdiri Metode Sosialisasi dan Focus Group Discussion (FGD). Hasil pengabdian: 1) Identifikas isu (a) kondisi lingkungan : sanitasi/kebersihan, abrasi pantai,air bersih, (b) rencana pembangunan di wilayah perencanaan: konflik daerah tangkapan, konflik pembudidaya ikan dengan nelayan, (c) kesejahteraan sosial ekonomi: pendidikan rendah, pemasaran hasil perikanan, kelembagaan masyarakat, pertumbuhan penduduk, produksi perikanan, (d) pemanfaatan sumberdya perikanan:Kerusakan terumbu karang, produksi rumput laut yang rendah, 2) Tersusunnya dokumen pengelolaan sumberdaya pesisir berbassis masyarakat Desa Batu nampar Selatan
\end{abstract}

Panduan Sitasi (APPA $7^{\text {th }}$ edition) :

Husni, S., Sukardi, L., Yusuf, M., Nursan, M., \& Utama FR, A.F.,. (2021). Penyusunan Rencana Pengelolaan Sumberdaya Pesisir Berbasis Masyarakat Di Desa Batu Nampar Selatan Kebupaten Lombok Timur. Jurnal Pengabdian Perikanan Indonesia, 1 (1), 43-54. http://doi.org/ 10.29303/jppi.v1i1.126

\section{PENDAHULUAN}

Sebagaimana diketahui potensi sumberdaya alam dan jasa lingkungan yang ada di wilayah yang terkenal paling produktif di dunia ini mempunyai makna yang sangat penting. Fakta menunjukkan bahwa sekitar $60 \%$ rakyat Indonesia hidup dan menggantungkan hidupnya di wilayah pesisir. Oleh karenanya apabila kelestarian dan keberlanjutan pemanfaatan sumberdaya alam dan jasa lingkungan yang ada ingin tetap dipertahankan, maka diperlukan komitmen dari semua pihak (stakeloders) untuk menjaga dan mengelola kualitas dan daya dukung lingkungan wilayah yang unik tersebut (Tulungen, et.al, 2003). 
Semakin pesatnya pertumbuhan penduduk penduduk membuat ancaman terhadap keberadaan sumberdaya pesisir itu sendiri semakin besar. Dampaknya adalah eksploitasi besarbesaran sumberdaya pesisir terutama dalam usaha-usaha eksensifikasi wilayah peruntukan yang dapat memacu pertumbuhan ekonomi. Pengabaian terhadap tata ruang wilayah pesisir, serta rendahnya keterlibatan masyarakat akan bermuara pada kurang optimalnya pengelolaan sumberdaya wilayah pesisir (Tulungen, et.al, 2003).

Salah satu upaya penting yang menjadi kunci keberhasilannya adalah keterlibatan masyarakat, mengingat upaya menjaga dan mengelola tersebut hanya dapat dicapai jika masyarakat dan pemangku kepenting (stakeholders) lainnya memiliki informas, pemahaman dan visi yang sama dalam mengelola sumberdaya. Pembinaan dan pengembangan masyarakat pesisir bisa berhasil dengan baik hanya jika stakeholders utamanya masyarakat pesisir berpartisipasi secara aktif (Dahuri, et al., 1987).

Di Indonesia, dengan dikeluarkannya UU No.22 tahun 1999 yang memberi kewenangan daerah dalam mengelola pesisir dan lautnya sejauh 12 mil untuk provinsi dan 4 mil untuk kabupaten memberikan peluang yang besar bagi pendekatan pengelolaan pesisir berbasis masyarakat.

Pendekatan dalam pengelolaan pesisir berbasis masyarakat ini belum banyak dipraktekan di Indonesia, pada hal dua per tiga wilayah Indonesia adalah laut, termasuk di Propinsi NTB khususnya Kabupaten Lombok Timur. Pengelolaan sumberdaya pesisir selama ini hanya ditangani secara temporal dan bersifat sektoral, dan tidak melibatkan masyarakat sehingga penanganannya tidak berkelanjutan dan tidak terpadu. Oleh karena itu perlu ada perencanaan yang matang dalam pengelolaan sumberdaya dengan melibatkan masyarakat dan stakeholders lainnya.

Desa Batu Nampar Selatan Kecamatan Jerowaru sebagai salah satu desa yang terletak di pesisir bagian barat Teluk Ekas, sebagian besar masyarakatnya menggantungkan hidupnya pada sektor perikanan yaitu sebagai nelayan dan pembudidaya ikan dan petambak garam. Untuk mencapai kesinambungan dan keberlanjutan dalam pemanfaatan sumberdaya pesisir tersebut penggalian isu dan dalam pemanfaatan sumberdaya pesisir secara komprehensif yang melibatkan seluruh masyarakat di desa ini menjadi kunci keberhasilan dalam pengelolaan wilayah pesisir yang berkelanjutan.

Dalam pemanfaatan sumberdaya pesisir sejak perencanaan sampai dengan monev, seringkali keterlibatan masyarakat sangat rendah sekali. Seringkal aktivitas pengelolaan sumberdaya pesisir didominasi oleh stakeolders yang lain, sehingga masyarakat hanya sebagai penonton dan obyek semata. Akibatnya masyarakat kurang peduli dalam memanfaatkan sumberdaya pesisir tersebut

Tujuan Pengabdian pada masyarakat adalah: 1) Mengidentifikasi isu dan permasalahan yang dihadapi masyarakat dalam pemanfaatan sumberdaya pesisir di Desa Batu Nampar Selatan dan 2) Menyusun Rencana Pengelolaan sumberdaya pesisir Pesisir di Desa Batu Nampar Selatan

\section{Manfaat}

1) Salah satu contoh (pilot) dalam perencanaan pengelolaan sumberdaya pesisir yang berbasis masyarakat

2) Sebagai salah satu acuan perencanaan Pemerintahan Desa Batu Nampar Selatan dalam Pengelolaan Sumberdaya Pesisir 


\section{METODE PELAKSANAAN}

Metode pelaksanaan penyusunan Rencana Pengelolaan sumberdaya Pesisir berbasis masyarakat ini terdiri Metode Sosialisasi dan Focus Group Discussion (FGD). Metode Sosialisasi merupakan langkah awal dalam pelaksanaan program. Meskipun terlihat sepele dan ringan, namun proses sosialisasi sangat berpengaruh terhadap keberlanjutan program. Sehingga seorang fasilitator harus sangat berhati-hati dalam proses sosialisasi, mengingat kondisi masyarakat yang sangat heterogen, baik tingkat pendidikan, karakter, daya terima dan pemahaman masyarakat. Dalam proses sosialisasi seorang fasilitator setidaknya melakukan sosialisasi terkait personal dirinya, seperti nama, asal, maksud dan tujuan datang ke wilayah tersebut, kemudian melakukan sosialisasi program seperti nama program, tujuan program, konsep program, jangka waktu pelaksanaan, sasaran dan target program (Hidayat, M., Surochiem, 2008).

Selanjutnya Metode Focus Group Discussion (FGD). Diskusi Kelompok Terarah merupakan suatu proses pengumpulan informasi mengenai suatu masalah tertentu yang sangat spesifik (Irwanto, 2007). Diskusi kelompok terarah adalah wawancara dari sekelompok kecil orang yang dipimpin seorang narasumber atau moderator yang mendorong peserta untuk berbicara terbuka dan spontan tentang hal yang dianggap penting dan berkaitan dengan topik saat itu.

Tujuan dari Diskusi Kelompok Terarah itu sendiri adalah untuk memperoleh masukan atau informasi mengenai permasalahan yang bersifat lokal dan spesifik. Penyelesaian masalah ini ditentukan oleh pihak lain setelah informasi berhasil dikumpulkan dan dianalisis.

Proses FGD dengan stakeholder dalam 2 tahap:

a. Tahap I dilakukan bersama dengan informan kunci yaitu Kepala desa dan perangkatnya ketua RT, kepala Dusun, Perwakilan kelompok nelayan, perwakilan pemuda, perwakila perempuan, tokoh Agama dan Tokoh masyarakat. Pada tahap I adalah penggalian isu atau perkembangan dan kondisi isu beserta lokasi dan penyebarannya, penyebab (oleh aktivitas manusia atau alamiah, akibat yang ditimbulkan (dampak ekologis, ekonomis atau kondisi sosial masyarakat), dan penanganan yang mungkin sudah dilakukan atau akan dilakukan serta keterkaitan isu tersebut dengan isu lain.

b. Tahap II, adalah rapat Pleno yang membahas pandangan umum tentang hasil Rapat I dan kesepakatan tentang Rencana Pengelolaan Pesisir Desa Batu Nampar Selatan dalam bentuk dokumen. Dokumen ini akan ditandatangai oleh Kepala Desa

\section{HASIL KEGIATAN}

Kegiatan penyusunan Rencana Pengelolaan Sumberdaya Pesisir berbasis masyarakat dilaksanakan di tempat pelelangan ikan, mengingat aula kantor desa setempat masih dalam tahap renovasi. Dilaksanakan pada hari Minggu tanggal 16 September 2020,. Peserta yang hadir berjumlah 30 orang terdiri dari tokoh masyarakat, tokoh pemuda, kaum perempuan, Sekerataris Desa, Kepala Dusun, dan Ketua RT.

Pertemuan dilaksanakan dalam kondisi new normal akibat pandemi covied-19, maka pertemuan dilakukan tetap mematuhi $3 \mathrm{M}$ yaitu mencuci tangan pakai sabun atau hand senataiser, menjaga jarak 1-2 meter, dan memakai masker. Acara pertemuan dibuka langsung oleh sekretaris desa Batu Nampar Selatan dan kemudian dilanjutkan diskusi dengan peserta. Peserta diminta mengemukaan persoalan yang dihadapi dalam pemanfaatan sumberdaya pesisir yaitu dari sisi sosial, ekonomi, lingkungan

Secara ringkas hasil diskusi sebagai berikut: 


\section{A. Isu Kondisi Lingkungan}

1. Sanitasi/Kebersihan

Penanganan kebersihan lingkungan di Desa Batu Nampar Selatan masih kurang mendapat perhatian dari masyarakat, sehingga menimbulkan wabah penyakit yang dapat menurunkan derajat kesehatan masyarakat. Fenomena ini disebabkan adanya kebiasaan masyarakat membuang sampah termasuk kotoran manusia di sembarang. Kurangnyanya fasilitas jamban sekitar $30 \%$ dari rumah tangga

\section{Abrasi Pantai}

Tidak adanya pohon pelindung yang disebabkan oleh penggundulan hutan karena aktivitas perladangan dan ditambah lagi adanya gelombang laut yang besar pada bulan-bulan tertentu merupakan faktor penting yang menyebabkan terjadinya abrasi pantai khususnya di Dusun Batunampar Utara

\section{Air bersih}

Desa Batu Nampar Selatan merupakan desa yang selalu mengalami krisis air bersih untuk kebutuhan sehari-hari, terutama pada saat musim kemarau. Untuk memenuhi kebutuhan air bersih, masyarakat harus mengeluarkan biaya yang cukup besar untuk membeli air. Sumber air bor di hanya ada di Dusun Temayang yang tidak sebanding dengan kebutuhan warga

\section{B. Kebijakan di Wilayah Perencanaan}

1. Konflik wilayah Penangkapan

Untuk mencegah terjadinya tumpang tindih dan konflik daerah jalur penangkapan di wilayah laut. Pemerintah Daerah telah mengeluarkan kebijakan wilayah jalur penangkapan nelayan dengan membagi : a) Jalur 1 diperuntukan nelayan kecil dengan jenis alat tangkap: pukat, jaring nilon, pancing, b) Jalur 2 digunakan nelayan besar seperti nelayan purse sine. Namun aturan atau kebijakan pembagian wilayah penangkapan tidak dipatuhi nelayan.

\section{Konflik Pembudidaya ikan dengan nelayan Tangkap}

Aktifitas penangkapan ikan yang tidak ramah lingkungan seperti penggunaan potasium sekitar area keramba jaring apung (KJA) berdampak terhadap penurunan produksi ikan budidaya. Penangkapan secara ilegal ini dilakukan oleh nelayan dari desa lain yang tidak bisa dicegah oleh masyarakat khususnya pembudidaya ikan.

\section{Isu Kesejahteraan Sosial Ekonomi \\ 1. Pendidikan yang rendah}

Pendidikan yang rendah berdampak terhadap tingkat pendapatan dan kesejahteraan rendah. Sebagian besar masyarakat di desa ini menggantungkan hidupnya dari aktivitas sebagai nelayan

\section{Pemasaran Hasil Perikanan}

Pemasaran hasil perikanan baik oleh nelayan (produsen) maupun oleh pedagang pengumpul (bakulan) sering mengalami fluktuasi. Selain karena kondisi musim juga harga ikan didtentukan oleh tengkulak.Begitu juga dengan sarana dan prasarana

\section{Kelembagaan Masyarakat}

Kelembagaan masyarakat cukup banyak seperti kelompok nelayan, kelompok pengawas perikanan. Namun tujuan dan manfaat organisasi tersebut belum memberikan kontribusi yang maksimal. Kebanyakan kelompok dibentuk tersebut tidak berjalan sebagaimana mestinya 


\section{Pertumbuhan penduduk}

Pertumbuhan penduduk yang cdpat merupakan masalah, mengignat kebanyakan masyarakat menikah pada usia muda dan kesadaran ber KB rendah

\section{Produksi Perikanan}

Produksi hasil tangkapan ne;ayan rata-rata tidak sesuai dengan waktu dan biaya yang dikeluarkan. Kebanyakan nelayan masih menggunakan armada dan alat tangkap sederhana, sehingga kemampuan nelayan untuk menangkap ikanm ke tempat yang jauh dangat terbatas

\section{Pemanfaatan Sumberdaya Perikanan}

1. Kerusakan terumbu karang

Kerusakan terumbu karang di Desa Batu Nampar Selatan didominasi oleh aktivitas manusia seperti pengeboman dan potasium oleh masyarakatdari luar desa tersebut

\section{Perikanan Tangkap}

Nelayan di Desa Batu Nampar Selatan sebagaian besar nelayan kecil. Keberadaan nelayan tersebut dari sisi sosiol ekonominya yang lemah. Penyediaan sarana dan prasarana melaut (perahu, mesin dan alat tangkap) adalah solusi yang tepat untuk meningkatkan kesejahteraan mereka.

\section{Budidaya rumput laut}

Budidaya rumput laut merupakan salah satu aktivitas nelayan untuk menambah penghasilan dan pendapatan. Di samping itu rumput laut memilki peluang pasar yang cukup menjanjikan. Di desa ini budidaya rumput laut akhir-akhir ini sudah mulai berkurang bahkan tidak ada lagi, pada hal potensi perairan dan kondisi lingkungan masih mendukung dan kondusif untuk kegiatan ini

Penyusunan Rencana Pengelolaan Pesisir Berbasis Masyarakat dimksud untuk memberikan arahan dan pedoman dalam pelaksanaan pengelolaan (pemanfaatan dan konservasi) sumberdaya pesisir di Desa Batu Nampar Selatan secara berkelanjutan. Tujuan yang ingin dicapai adalah menjamin ketersediaan sumberdaya pesisir baik pada masa sekarang maupun di masa yang akan datang, melalui pengkajian isu dan permasalahan pemanfaatan sumberdaya perikanan, degradasi lingkungan, kebijakan pengelolaan dan. kondisi sosial ekonomi dan kelembagaan

\section{E. Tujuan, Sasaran, Strategi, dan Jangka Waktu Pelaksanaan Program}

1. Pemanfaatan Sumberdaya Pesisir

Tujuan:

1. Melindungi dan melestarikan ekosistem terumbu karang dan mangrove.

2. Mengembangkan kegiatan usaha budidaya laut.

3. Meningkatkan peran serta masyarakat dalam pengelolaan sumberdaya perikanan.

4. Meningkatkan keteremapilan masyarakat melalui penerapan Teknologi Tepat Guna. Sasaran

Terwujudnya pengelolaan sumberdaya pesisir di Desa Batu Nampar Selatan cara partisipatif dan berkelanjutan. 


\begin{tabular}{|c|c|c|c|c|}
\hline \multirow{2}{*}{$\begin{array}{c}\text { Strategi dan Kegiatan yang akan } \\
\text { dilakukan }\end{array}$} & \multirow{2}{*}{ Lembaga Pelaksana } & \multicolumn{3}{|c|}{ Jangka Waktu Program (tahun) } \\
\hline & & $\begin{array}{l}\text { Pendek } \\
\text { (2021) }\end{array}$ & $\begin{array}{l}\text { Menengah } \\
(2021-2026)\end{array}$ & $\begin{array}{c}\text { Panjang } \\
(2021-2046)\end{array}$ \\
\hline $\begin{array}{l}\text { Pembentukan daerah perlindungan } \\
\text { laut }\end{array}$ & $\begin{array}{l}\text { Diskanlut, LSM, PT, } \\
\text { Masyarakat }\end{array}$ & & $\sqrt{ }$ & \\
\hline $\begin{array}{l}\text { Rehabilitasi terumbu karang yang } \\
\text { rusak }\end{array}$ & $\begin{array}{l}\text { Diskanlut, KSDA, } \\
\text { LSM. PT }\end{array}$ & & $\sqrt{ }$ & \\
\hline Pengembangan usaha budidaya laut & $\begin{array}{l}\text { Diskanlut, } \\
\text { Masyarakat, } \\
\text { Investor }\end{array}$ & & $\sqrt{ }$ & \\
\hline $\begin{array}{l}\text { Pelatihan masyarakat dalam } \\
\text { menjaga kelestarian sumberdaya } \\
\text { pesisir dan laut. }\end{array}$ & $\begin{array}{l}\text { Pemenrintahan } \\
\text { Desa,LSM }\end{array}$ & $\sqrt{ }$ & & \\
\hline $\begin{array}{l}\text { Peningkatan peran masyarakat } \\
\text { terhadap pengawasan laut. }\end{array}$ & $\begin{array}{l}\text { Pemerintahan Desa, } \\
\text { Diskanlut }\end{array}$ & 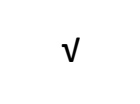 & & \\
\hline $\begin{array}{l}\text { Rehabilitiasi terumbu karang dengan } \\
\text { menggunakan terumbu karang } \\
\text { buatan. }\end{array}$ & Diskanlut, KSDA & & $\sqrt{ }$ & \\
\hline $\begin{array}{l}\text { Peningkatan kesadaran masyarakat } \\
\text { dalam pengelolaan SDPL. }\end{array}$ & $\begin{array}{l}\text { Pemenrintahan } \\
\text { Desa, LSM }\end{array}$ & $V$ & & \\
\hline $\begin{array}{l}\text { Peningkatan keterampilan } \\
\text { masyarakat }\end{array}$ & $\begin{array}{l}\text { Pemerintahan Desa, } \\
\text { LSM }\end{array}$ & $\mathrm{V}$ & & \\
\hline $\begin{array}{l}\text { Penyuluhan, Pembinaan dan } \\
\text { pendampingan Masyrakat dalam } \\
\text { mengelola SDPL. }\end{array}$ & $\begin{array}{l}\text { Pemerintahan } \\
\text { Desa, LSM }\end{array}$ & $\mathrm{V}$ & & \\
\hline $\begin{array}{l}\text { Penguatan kapasitas kelembagaan } \\
\text { pokmaswas }\end{array}$ & Dana Desa & $\mathrm{V}$ & & \\
\hline $\begin{array}{l}\text { Pembuatan aturan lokal atau } \\
\text { Peraturan Daerah (perda) tentang } \\
\text { sumberdaya perikanan. }\end{array}$ & Dana Desa & $\sqrt{ }$ & $\sqrt{ }$ & \\
\hline $\begin{array}{l}\text { Desain alat tangkap yang ramah } \\
\text { lingkungan. }\end{array}$ & Dana Desa & $\mathrm{V}$ & & \\
\hline
\end{tabular}




\begin{tabular}{|c|c|c|c|c|}
\hline \multirow{2}{*}{$\begin{array}{c}\text { Strategi dan Kegiatan yang akan } \\
\text { dilakukan }\end{array}$} & \multirow[b]{2}{*}{ Lembaga Pelaksana } & \multicolumn{3}{|c|}{ Jangka Waktu Program (tahun) } \\
\hline & & $\begin{array}{l}\text { Pendek } \\
\text { (2021) }\end{array}$ & $\begin{array}{l}\text { Menengah } \\
(2021-2026)\end{array}$ & $\begin{array}{c}\text { Panjang } \\
(2021-2046)\end{array}$ \\
\hline $\begin{array}{l}\text { Re-stocking terhadap ikan ikan } \\
\text { terumbu karang (kerapu dan lobster) }\end{array}$ & $\begin{array}{l}\text { Diskanlut, KSDA, } \\
\text { LSM, PT }\end{array}$ & & $\sqrt{ }$ & $\sqrt{ }$ \\
\hline $\begin{array}{l}\text { Penerapan TTG dalam pengelolaan } \\
\text { hasil tangkap. }\end{array}$ & Dana Desa & v & & \\
\hline $\begin{array}{l}\text { Bantuan modal untuk } \\
\text { pengembangan usaha. }\end{array}$ & Dana Desa & $\mathrm{V}$ & & \\
\hline Pembinaan dan penyuluhan. & Dana Desa & $\mathrm{V}$ & & \\
\hline $\begin{array}{l}\text { Penyadaran masayrakat tentang } \\
\text { pentingnya SDPL }\end{array}$ & Dana Desa & $\sqrt{ }$ & & \\
\hline $\begin{array}{l}\text { Memperluas alternatif mata } \\
\text { pencaharian diluar sektor perikanan. }\end{array}$ & $\begin{array}{l}\text { Diskanlut, Pemda, } \\
\text { PMD }\end{array}$ & & V & $\sqrt{ }$ \\
\hline
\end{tabular}

\section{Lingkungan}

Tujuan:

1. Meingkatkan kualitas pelayanan kesehatan pada masyarakat pesisir .

2. Meningkatkan Fasilitas sarana dan prasarana kebersihan dan kesehatan lingkungan.

3. Meningkatkan kesadaran masyarakat tentang kebersihan dan kesehatann lingkungan. Sasaran:

Terwujudnya pengelolaan lingkungan masyarakat pesisir yang bersih dan sehat secara partisipatif.

\begin{tabular}{|l|l|c|c|c|}
\hline \multirow{2}{*}{$\begin{array}{c}\text { Strategi dan Kegiatan yang akan } \\
\text { dilakukan }\end{array}$} & Lembaga Pelaksana & \multicolumn{2}{|c|}{ Jangka Waktu Program (tahun) } \\
\cline { 3 - 5 } & Pendek & $\begin{array}{c}\text { Menengah } \\
\text { (2022-2026) }\end{array}$ & $\begin{array}{c}\text { Panjang } \\
\text { (2021-2046) }\end{array}$ \\
\hline $\begin{array}{l}\text { Pengembangan program - program } \\
\text { pengelolaan lingkungan dengan } \\
\text { melibatkan masyarakat secara } \\
\text { partisipatif. }\end{array}$ & Bum Desa & $v$ & & \\
\hline $\begin{array}{l}\text { Meningkatkan fasilitas sarana dan } \\
\text { prasarana kesehatan. }\end{array}$ & $\begin{array}{l}\text { Dislutkan, Dikes, } \\
\text { Diskimpraswil, } \\
\text { Bappeda }\end{array}$ & & & \\
\hline
\end{tabular}




\begin{tabular}{|l|l|c|c|c|}
\hline \multirow{2}{*}{$\begin{array}{l}\text { Strategi dan Kegiatan yang akan } \\
\text { dilakukan }\end{array}$} & Lembaga Pelaksana & \multicolumn{2}{c|}{ Jangka Waktu Program (tahun) } \\
\cline { 3 - 5 } & & Pendek & $\begin{array}{c}\text { Menengah } \\
\text { (2022-2026) }\end{array}$ & $\begin{array}{c}\text { Panjang } \\
\text { (2021-2046) }\end{array}$ \\
\hline $\begin{array}{l}\text { Penyediaan sarana pembuangan } \\
\text { limbah rumah tangga. }\end{array}$ & $\begin{array}{l}\text { LSM, Dislutkan, } \\
\text { Dikes, Pemda (lingk } \\
\text { hidup) }\end{array}$ & & $\checkmark$ & \\
\hline $\begin{array}{l}\text { Peningkatan kesadaran masyarakat } \\
\text { melalui penyuluhan dan pembinaan } \\
\text { tentang kebersihan dan kesehatan } \\
\text { lingkungan. }\end{array}$ & Bum Desa & $v$ & & \\
\hline $\begin{array}{l}\text { Menbuat sumur bor di masing- } \\
\text { masing lingkungan }\end{array}$ & $\begin{array}{l}\text { Dinas PU, } \\
\text { Pemerintahan Desa }\end{array}$ & $v$ & & \\
\hline $\begin{array}{l}\text { Penanaman mangrove (pohon } \\
\text { pelindung dipinggir pantai }\end{array}$ & $\begin{array}{l}\text { Dislutkan, dan } \\
\text { pemenrintahan desa }\end{array}$ & & & \\
\hline
\end{tabular}

\section{Kebijakan di Wilayah Perencanaan} Tujuan:

1. Meningkatkan peran dan fungsi kelembagaan POKMASWAS.

2. Membuat aturan pengelolaan dan perlindungan sumberdaya pesisir dan laut.

3. Menegakkan aturan pengelolaan yang dibuat secara partisipatif oleh masyarakat.

\section{Sasaran:}

Terbentuknya kebijakan pengelolaan sumberdaya pesisir dan laut di dengan melibatkan semua stakeholders yang berkepentingan.

\begin{tabular}{|l|l|c|c|c|}
\hline \multicolumn{1}{|c|}{$\begin{array}{c}\text { Strategi dan Kegiatan yang akan } \\
\text { dilakukan }\end{array}$} & Lembaga Pelaksana & \multicolumn{3}{c|}{ Jangka Waktu Program (tahun) } \\
\cline { 3 - 5 } & $\begin{array}{c}\text { Pendek } \\
\text { (2021) }\end{array}$ & $\begin{array}{c}\text { Menengah } \\
\text { (2021-2026) }\end{array}$ & $\begin{array}{c}\text { Panjang } \\
\text { (2021-2046) }\end{array}$ \\
\hline $\begin{array}{l}\text { Penertiban jalur penangkapan sesuai } \\
\text { dengan zonasi yang sudah disepakati } \\
\text { bersama dengan masyarakat. }\end{array}$ & Diskanlut & $v$ & \\
\hline $\begin{array}{l}\text { Penegakan aturan hukum bagi } \\
\text { masyarakat yang melanggar jalur } \\
\text { penangkapan dalam bentuk Awiq- } \\
\text { awiq }\end{array}$ & Pemerintahan Desa & $v$ & & \\
\hline Peningkatan fungsi Pokmaswas & Pemerintahan Desa & $v$ & & \\
\hline
\end{tabular}




\begin{tabular}{|l|l|c|c|c|}
\hline \multicolumn{1}{|c|}{$\begin{array}{l}\text { Strategi dan Kegiatan yang akan } \\
\text { dilakukan }\end{array}$} & Lembaga Pelaksana & \multicolumn{2}{c|}{ Jangka Waktu Program (tahun) } \\
\cline { 3 - 5 } & & $\begin{array}{c}\text { Pendek } \\
\text { (2021) }\end{array}$ & $\begin{array}{c}\text { Menengah } \\
\text { (2021-2026) }\end{array}$ & $\begin{array}{c}\text { Panjang } \\
\text { (2021-2046) }\end{array}$ \\
\hline $\begin{array}{l}\text { Pembuatan aturan lokal tentang } \\
\text { perlidungan dan pengelolaan } \\
\text { sumberdaya pesisir dan laut }\end{array}$ & $\begin{array}{l}\text { Pemerintahan Desa, } \\
\text { LSM, Diskanlut }\end{array}$ & $V$ & & \\
\hline $\begin{array}{l}\text { Penataan lokasi untuk kegiatan } \\
\text { budidaya laut }\end{array}$ & Diskanlut & $V$ & & \\
\hline $\begin{array}{l}\text { Penguatan kelembagaan pada } \\
\text { kelompok masyarakat pengawas } \\
\text { (Pokmaswas) }\end{array}$ & LSM, Diskanlut & V & & \\
\hline $\begin{array}{l}\text { Pemanfaatan jalur penangkapan } \\
\text { untuk jalur I dan II melalui } \\
\text { peningkatan kapasitas sarana } \\
\text { penangkapan. }\end{array}$ & Diskanlut & Diskanlut & V & \\
\hline $\begin{array}{l}\text { Sosialisasi mengenai pembagian } \\
\text { jalur daerah penangkapan. }\end{array}$ & & & & \\
\hline
\end{tabular}

\section{Kesejahteraan Sosial Ekonomi}

Tujuan:

1. Meningkatkan kualitas SDM dalam mengelola kawasan pesisir dan laut.

2. Meningkatkan kpasitas sarana penangkapan dan pengembangan teknik budidaya laut.

3. Mengembangkan jaringan pasar hasil perikanan tangkap dan budidaya

4. Meningkatkan kemitraan antara masyarakat dan pengusaha (lembaga perekonomian)

5.

Sasaran:

Meningkatnya kesejahteraan masyarakat pesisir dan nelayan.

\begin{tabular}{|l|l|c|c|c|}
\hline \multirow{2}{*}{$\begin{array}{l}\text { Strategi dan Kegiatan yang akan } \\
\text { dilakukan }\end{array}$} & Lembaga Pelaksana & \multicolumn{3}{|c|}{ Jangka Waktu Program (tahun) } \\
\cline { 3 - 5 } & & $\begin{array}{c}\text { Pendek } \\
\text { (2021) }\end{array}$ & $\begin{array}{c}\text { Menengah } \\
\text { (2006-2022) }\end{array}$ & $\begin{array}{c}\text { Panjang } \\
\text { (2021-2046) }\end{array}$ \\
\hline $\begin{array}{l}\text { Mengembangkan jaringan pasar } \\
\text { melalui peningkatan kualitas hasil } \\
\text { tangkapan dan hasil-hasil budidaya }\end{array}$ & Pemerintahan Desa & $v$ & & \\
\hline $\begin{array}{l}\text { Meningkatkan program } \\
\text { pemberdayaan masyarakat melalui } \\
\text { pendampingan tenaga terdidik dan }\end{array}$ & $\begin{array}{l}\text { Dislutkan, PMD, } \\
\text { Diknas }\end{array}$ & & $v$ & \\
\hline
\end{tabular}




\begin{tabular}{|c|c|c|c|c|}
\hline \multirow{2}{*}{$\begin{array}{c}\text { Strategi dan Kegiatan yang akan } \\
\text { dilakukan }\end{array}$} & \multirow{2}{*}{ Lembaga Pelaksana } & \multicolumn{3}{|c|}{ Jangka Waktu Program (tahun) } \\
\hline & & $\begin{array}{l}\text { Pendek } \\
\text { (2021) }\end{array}$ & $\begin{array}{l}\text { Menengah } \\
(2006-2022)\end{array}$ & $\begin{array}{c}\text { Panjang } \\
(2021-2046)\end{array}$ \\
\hline $\begin{array}{l}\text { terlatih pada masyarakat pesisir } \\
\text { dalam mengembangkan usaha. }\end{array}$ & & & & \\
\hline $\begin{array}{l}\text { Sosialisasi dan menjalin kemitraan } \\
\text { antara masyarakat dengan } \\
\text { pengusaha untuk pengembangan } \\
\text { modal usaha. }\end{array}$ & $\begin{array}{l}\text { Dislutkan, Investor. } \\
\text { Disperindang }\end{array}$ & & 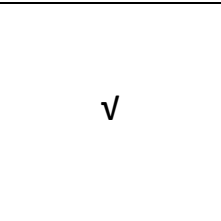 & \\
\hline $\begin{array}{l}\text { Pelatihan kewirausahaan untuk } \\
\text { membina masyarakat } \\
\text { mengembangkan potennsi usaha } \\
\text { yang bergerak dalam bidang } \\
\text { pengelolaan SDPL. }\end{array}$ & Pemenritahan Desa & $\sqrt{ }$ & & \\
\hline $\begin{array}{l}\text { Mengembangkan alternatif } \\
\text { pekerjaan diluar kegiatan } \\
\text { penangkapan dan budidaya } \\
\text { (perbengkelan, pengolahan } \\
\text { makanan tradisional, dan lain lain) }\end{array}$ & $\begin{array}{l}\text { Dislutkan, pemda, } \\
\text { PMD }\end{array}$ & & & $\sqrt{ }$ \\
\hline $\begin{array}{l}\text { Pelatihan keterampilan untuk } \\
\text { penanganan pengelolaan hasil } \\
\text { tangkap dan budidaya. }\end{array}$ & Pemerintahan Desa & $\sqrt{ }$ & & \\
\hline $\begin{array}{l}\text { Penguatan kelembagaan ekonomi } \\
\text { yang dibentuk oleh masyarakat } \\
\text { melalui kegiatan pelatihan dan } \\
\text { peningkatan kerjasama dengan } \\
\text { lembaga perekonomian pemerintah } \\
\text { (bank) dan swasta. }\end{array}$ & $\begin{array}{l}\text { Dislutkan, Pemda, } \\
\text { PMD }\end{array}$ & & $\sqrt{ }$ & \\
\hline $\begin{array}{l}\text { Peningkatan kapasitas saranan } \\
\text { penangkapan dan pengembangan } \\
\text { lembaga perekonomian untuk } \\
\text { penambahan modal usaha. }\end{array}$ & $\begin{array}{l}\text { Dislutkan, Pemda, } \\
\text { PMD }\end{array}$ & & $\sqrt{ }$ & \\
\hline $\begin{array}{l}\text { Menyediakan lapangan pekerjaan } \\
\text { sebagai alternatif matapencaharian } \\
\text { lain. }\end{array}$ & $\begin{array}{l}\text { Dislutkan, Pemda, } \\
\text { PMD }\end{array}$ & & & $v$ \\
\hline
\end{tabular}




\begin{tabular}{|c|c|c|c|c|}
\hline \multirow{2}{*}{$\begin{array}{c}\text { Strategi dan Kegiatan yang akan } \\
\text { dilakukan }\end{array}$} & \multirow{2}{*}{ Lembaga Pelaksana } & \multicolumn{3}{|c|}{ Jangka Waktu Program (tahun) } \\
\hline & & $\begin{array}{c}\text { Pendek } \\
\text { (2021) }\end{array}$ & $\begin{array}{c}\text { Menengah } \\
(2006-2022)\end{array}$ & $\begin{array}{c}\text { Panjang } \\
(2021-2046)\end{array}$ \\
\hline $\begin{array}{l}\text { Sosialisasi pada masyarakat tentang } \\
\text { peran dan fungsi lembaga } \\
\text { perekonomian yang dibentuk oleh } \\
\text { masyarakat meupun lembaga } \\
\text { perekonomian yang dibentuk oleh } \\
\text { pemerintah dan swasta. }\end{array}$ & $\begin{array}{l}\text { Dislutkan, Pemda, } \\
\text { PMD }\end{array}$ & & & $\mathrm{v}$ \\
\hline $\begin{array}{l}\text { Pelatihan manajemen pemasaran } \\
\text { hasil pengelolaan SDPL. }\end{array}$ & Pemerintahan Desa & $\mathrm{v}$ & & \\
\hline
\end{tabular}

\section{KESIMPUAN DAN SARAN}

\section{Kesimpulan}

1. Identifikas isu (a) kondisi lingkungan : sanitasi/kebersihan, abrasi pantai,air bersih, (b) rencana pembangunan di wilayah perencanaan: konflik daerah tangkapan, konflik pembudidaya ikan dengan nelayan, (c) kesejahteraan sosial ekonomi: pendidikan rendah, pemasaran hasil perikanan, kelembagaan masyarakat, pertumbuhan penduduk, produksi perikanan, (d) pemanfaatan sumberdya perikanan: Kerusakan terumbu karang, produksi rumput laut yang rendah,

2. Dokumen pengelolaan sumberdaya pesisir desa Batu nampar Selatan Berbasis Masyarakat di Desa Btu Nampar Selatan telah disusun dan diterima oleh stakeholders dan ditandatangani oleh Kepala Desa.

\section{Saran}

1. Keterlibatan masyarakat menjadi salah satu indikator keberhasilan dalam penyusunan dan pelaksanaan pengelolaan wilayah pesisir berbasis masyarakat

2. Dokumen Rencana pengelolaan wilayah pesisir dapat dijadikan acuan dalam penyusunan dan alokasi dana desa.

\section{DAFTAR PUSTAKA}

Hermawan, T, Suwarno, Tarigan, Setiawan, Syarief, Bachitar, Ahmadi, Hidayat, Ardani., Pedoman Praktis Penyusunan Rencana Pengelolaan Perikanan Marginal Fishing Community Developmen (MFCDP), 2005. Bappenas, The World Bank, Departemen Kelautan dan Perikanan, Depdagri.

Husni,S., Abubakar, Efendy, Wathoni Sjah T, Farida Puspa, 2014. Pemilihan Mata Pencaharian Alternatif Nelayan Melalui Agribisnis Rumput Laut di Desa Batu Nampar Selatan Kabupaten Lombok Timur. Laporan PPM Universitas Mataram. Mataram.

Irwanto, 2016, Focused Group Discussion (FGD): Sebuah Pengantar Praktis. Yayasan Obor Indonesia. Jakarta. 
Rokhmin, D., Rais, Ginting, Sitepu, 1996. Pengelolaan Sumberdaya Wilayah Pesisir dan Lautan Secara Terpadu. PT. Pradnya Paramita. Jakarta.

Sukardi, L., Abubakar, Husni,S, Yusuf M., 2017. Peningkatan Kapasitas Masyarakat dan Kelembagaan Dalam Pengelolaan Daerah Perlindungan Laut (DPL) Sapak Perendang di Desa Batu Nampar Selatan Kabupaten Lombok Timur. Laporan PPM Universitas Mataram. Mataram

Tulungen, J., Kasmidi, Rotinsulu, Dimpidus, Tangkilisan, 2003. Panduan Pengelolaan Sumberdaya Wilayah Pesisir Berbasis Masyarakat. USAID-Indonesia Coastal Resoureces Managemen Project. Jakarta

Yayasan Laut Biru (YLB), GEF, SGP, UNDP, 2014. Pemberdayaan Masyarakat Pesisir Melalui Pengelolaan Daerah Perlindungan Laut (DPL) dan Mata Pencaharian Alternatif Secara Berkelanjutan di Teluk Ekas Lombok Timur. Laporan. Kerjasama YLB, GEF, SGP, UNDP. Mataram. 